\title{
Site-specific features affect pollination success of a gynodioecious understory shrub in a gender-specific mode ${ }^{1}$
}

\author{
Conchita ALONSO ${ }^{2}$ \& Carlos M. HERRERA, Estación Biológica de Doñana, Consejo Superior de \\ Investigaciones Científicas (CSIC), Avda. María Luisa s/n, Pabellón de Perú, 41013, Sevilla, Spain, \\ e-mail: conalo@ebd.csic.es
} Abstract: Daphne laureola (Thymelaeaceae) is a gynodioecious, winter-flowering shrub inhabiting the understory of shady
mountain forests. The small, inconspicuous yellowish-green flowers are pollinated by ectothermic insects whose activity is
mainly confined to infrequent spells of sunny weather. We tested the hypotheses that (1) the solar irradiance environment of
individual $D$. laureola plants and distance to the nearest conspecific should influence their pollination success and (2) the
effect of both site-specific features on pollination success should be sex-dependent, given the difference between female and
hermaphrodite flowers in conspicuousness and floral rewards. We estimated maternal pollination success (mean number of
pollen tubes/pistil and proportion of unfertilized flowers), measured the distance to the nearest flowering conspecific, and
evaluated the irradiance environment (percent of canopy cover) for individual $D$. laureola plants in 7 southeastern Spanish
populations. On average, hermaphrodite flowers were pollinated more often and had more pollen tubes/pistil than females.
Distance to the nearest conspecific affected individual pollination success negatively, but the effect was significant only for
females. Furthermore, there existed a highly significant sex $\times$ cover interaction effect on pollination success. Among female
individuals, the number of pollen tubes/pistil decreased and the proportion of unfertilized flowers increased from closed to
more open sites, while hermaphrodites showed non-significant and opposite trends. The contrasting sign of the relationship
between cover and pollination success for the 2 genders is expected to generate a fine-scale, within-habitat mosaic in the
magnitude of the pollination advantage of hermaphrodite individuals, which would be greater in the more open, sunny locations
where ectothermic pollinators should be more active. Site-specific differences in relative pollination success of sexes might
contribute to the persistence of gynodioecy of $D$. laureola in our study region.
Keywords: abiotic conditions, beetle pollination, canopy cover, Daphne laureola, distance to the nearest neighbour, gynodioecy, hemispherical canopy photographs, microhabitat, winter flowering.

Résumé : Daphne laureola (Thymelaeaceae) est un arbuste gynodioïque à floraison hivernale qui habite le sous-étage de forêts ombragées de montagne. Ses petites fleurs jaunâtre-vertes peu visibles sont pollinisées par des insectes ectothermiques dont l'activité est principalement limitée aux rares périodes de temps ensoleillé. Nous avons évalué les hypothèses que (1) l'environnement radiatif solaire des plants de D. laureola et la distance à l'individu conspécifique le plus proche devrait influencer leur succès de pollinisation et (2) l'effet des caractéristiques spécifiques du site sur le succès de pollinisation devrait dépendre du sexe, étant donné la différence entre les fleurs femelles et hermaphrodites quant à leur visibilité et à leur récompense florale. Nous avons évalué le succès de pollinisation maternel (le nombre moyen de tubes polliniques/pistils et la proportion de fleurs non fécondées), mesuré la distance à l'individu conspécifique en floraison le plus proche et évalué l'environnement radiatif (le pourcentage de fermeture du couvert) pour des plants individuels de $D$. laureola dans 7 populations du sud-est de l'Espagne. En moyenne, les fleurs hermaphrodites ont été pollinisées plus souvent et avaient plus de tubes polliniques/pistils que les fleurs femelles. La distance à l'individu conspécifique le plus proche a eu un effet négatif sur le succès de pollinisation individuel, mais cet effet n'était significatif que pour les femelles. De plus, l'interaction entre le sexe et le couvert était fortement significative pour le succès de pollinisation. Chez les individus femelles, le nombre de tubes polliniques/pistils a diminué et la proportion de fleurs non fécondées a augmenté des sites à couvert fermé à ceux plus ouverts, alors que les hermaphrodites ont démontré des tendances opposées, mais non significatives. On s'attend donc à ce que la relation inverse pour les 2 genres entre le couvert forestier et le succès de pollinisation crée une mosaïque à petite échelle au sein de l'habitat pour ce qui est de l'ampleur de l'avantage pollinique des individus hermaphrodites, cet avantage serait plus important dans les sites plus ouverts et ensoleillés où les pollinisateurs ectothermiques devraient être plus actifs. Les différences spécifiques du site quant au succès de pollinisation selon le sexe pourraient contribuer à la persistance de la gynodioécie chez $D$. laureola dans notre région d'étude.

Mots-clés : conditions abiotiques, couvert forestier, Daphne laureola, distance au voisin le plus proche, floraison hivernale, gynodioécie, microhabitat, photographies hémisphériques de la canopée, pollinisation par des coléoptères.

Nomenclature: Castroviejo et al., 1997.

\footnotetext{
${ }^{1}$ Rec. 2007-06-18; acc. 2007-12-28.

Associate Editor: Johannes Kollmann.

${ }^{2}$ Author for correspondence.

DOI 10.2980/15-3-3115
} 


\section{Introduction}

In animal-pollinated plants, individual variation in intrinsic flower and inflorescence features generally contributes to individual differences in pollination success and seed output, in accordance with the decisive selective role played by pollinators on these traits (Pellmyr, 2002). Nevertheless, consideration of the ecological context (i.e., the extrinsic biotic and abiotic conditions) in which the interaction of plants and pollinators takes place is also essential to a proper understanding of its evolutionary potential (Herrera, 1996; Galen, 1999; Ashman, 2006). The ecological context can affect the interaction of plants with their pollinating agents through a variety of mechanisms. For example, plants can respond to variations in the abiotic environment by plastically modifying certain features that may eventually affect their attractiveness to pollinators, such as floral display (Salonen, 1994; Schemske \& Bierzychudek, 2001; Totland, 2001), flower size and shape (Murcia, 1990; Herrera, 2005), nectar production (Petanidou \& Smets, 1996), and floral longevity and phenology (Peterson, 1997; Utelli \& Roy, 2001). In addition, spatio-temporal variations in abiotic conditions may induce changes in pollinator composition, abundance, and behaviour that will in turn give rise to differences in floral visitation, pollen export and receipt (Warren, Harper \& Booth, 1988; Eckhart, 1992; Herrera, 1995; Eckert, 2002; Alonso, 2005; Price et al., 2005; Ashman, 2006), and even the sign and strength of selection on floral traits (Caruso, Peterson \& Ridley, 2003; Herrera, Castellanos \& Medrano, 2006). Finally, the biotic environment, as represented by the diversity, local density, and spatial distribution of simultaneously flowering plants, may affect plant-animal interactions in general (see, e.g., Karban, 1997 and references therein for herbivory), particularly plant-pollinator interactions, through effects on insect activity, foraging behaviour, and pollination effectiveness (Laverty, 1992; Feldman, 2006; Metcalfe \& Kunin, 2006).

Each of the preceding effects can take place at different spatial scales, involving variations at the among- and within-plant population levels. In this paper we will focus on the pollination consequences of small-scale spatial variations in the ecological context, or "site-specific" effects, occurring at the within-population level. This aspect of plant-pollinator interactions has been only infrequently examined (but see Herrera, 1995; 1997; Orueta, 2002; Sánchez-Lafuente et al., 2005), but it is important because site-specific effects may limit the responses of plant populations to selection by pollinators on intrinsic floral traits (Herrera, 1996).

Microclimate and the distribution of conspecific flowering neighbours are possibly the 2 most important determinants of site-specific pollination effects within plant populations. Microclimatic effects on pollination success should be most apparent in plants pollinated by ectothermic insects that occupy habitats like the forest understory, characterized by patchiness in environmental variables potentially affecting pollinator foraging (Beattie, 1971; Herrera, 1995). The patterns of solar irradiance on a forest floor produce a changing mosaic of intensities, which provides a rich and varying array of microhabitats for plants and insects (Herrera, 1995; 1997). When flowers are larger than pollinators they may provide favourable environments in which shelter and temperature can be experienced by pollinators as a reward (Seymour, White \& Gibernau, 2003; Sapir, Schmida \& Neeman, 2006). On the other hand, the spatial distribution of conspecifics, and particularly the distance between neighbours, may contribute to generate site-specific effects on pollination success in species whose individuals depend strictly on pollen vectors for sexual reproduction (e.g., dioecious and self-incompatible hermaphroditic species; Widén \& Widén, 1990; Kunin, 1992; Metcalfe \& Kunin, 2006). Site-specific effects on pollination success related to variation in microclimate and spatial relationships to conspecifics are therefore expected to be most frequent among sexually polymorphic species pollinated by ectothermic insects.

In this paper we report on a study designed to evaluate the effects of the solar irradiance environment and distance to the nearest conspecific neighbour on the maternal pollination success of female and hermaphrodite individuals of Daphne laureola, a gynodioecious understory shrub. In gynodioecious species, pollen limitation of seed production of female plants often increases with distance to pollen donors (Widén \& Widén, 1990; Graff, 1999; but see Pettersson, 1997). However, we are not aware of any previous study on the effects of abiotic heterogeneity in sex-differential reproductive success in gynodioecious species (but see Barr, 2004 for an experimental approach). In our study region (see below), D. laureola typically grows in the understory of coniferous and mixed montane forests, all populations are gynodioecious, and female and hermaphrodite individuals are similar in size and floral display (Alonso \& Herrera, 2001). Individual female flowers are less conspicuous because of shorter corolla tubes and absence of pollen. Flowering starts during winter, and the species is mainly pollinated by a small, ectothermic nitidulid pollen beetle (Alonso, 2004). We tested the hypotheses that (1) the solar irradiance environment experienced by individual $D$. laureola plants, and the distance to the nearest neighbour, should influence their pollination success, and (2) the effect of site-specific variables on pollination success should be sex-dependent, given the difference between female and hermaphrodite flowers in the nature of floral rewards, conspicuousness, and dependence on pollinators for pollen receipt. We expected a stronger effect of isolation on the pollination success of female plants, but we did not have a priori expectations about the nature of gender-specific effects of the solar irradiance microenvironment.

\section{Methods}

\section{STUDY SPECIES AND SITES}

Daphne laureola (Thymelaeaceae) is an early-season flowering, evergreen shrub growing in the undergrowth of shady mountain forests. In the Iberian Peninsula, the species is frequent in the northern Cantabrian and Pyrenean Mountains and also in the southern Betic Ranges but is absent from the central Iberian Ranges (Alonso, Mutikainen \& Herrera, 2007). This study was conducted in 2002 in 7 different populations within the Natural Park of Sierras de Cazorla, Segura y Las Villas (Jaén province, southeastern Spain). These populations are a subset of those used in an earlier study on altitudinal gradients of pollination 
success (see Alonso, 2005 for further details) and encompass most of the species' altitudinal range in the region (see Table I). Distances between nearest sites range between 3 and $22 \mathrm{~km}$. All the study populations were located in old, well-preserved natural forests. A mixture of Pinus nigra, P. pinaster, and Quercus ilex dominated the evergreen canopy in all study sites except Coto del Valle, where the forest was largely dominated by Quercus faginea. Crataegus monogyna and Prunus mahaleb, 2 deciduous treelets, also occurred frequently in the overstory of our study sites. All deciduous species usually start leafing after $D$. laureola has completed flowering.

In the study region $D$. laureola populations consist of a mixture of hermaphrodite and female individuals, with female frequency being highly variable (3.8-64.3\%; 94 populations) and decreasing with elevation (Alonso \& Herrera, 2001). The small, tubular, yellowish-green flowers open synchronously in late winter and are aggregated into compact axillary inflorescences. Pistils have a single ovule. Female flowers have vestigial stamens that do not produce pollen and have shorter corolla tubes (mean $\pm \mathrm{SD}$ : $4.9 \pm 0.45 \mathrm{~mm}$, $n=45$ flowers) than the perfect flowers of hermaphrodites $(8.1 \pm 0.92 \mathrm{~mm}, n=56)$. Hermaphroditic plants are selfcompatible, but fruit production requires flower visitation by pollinators (Alonso \& Herrera, 2001). The pollen beetle Meligethes elongatus (Coleoptera: Nitidulidae) and, to a much smaller extent, small solitary bees and noctuid moths are the main pollinators (Alonso, 2004).

\section{SITE-SPECIFIC FEATURES OF INDIVIDUAL PLANTS}

Six female and 6 hermaphrodite $D$. laureola individuals were haphazardly chosen in each of the 7 study populations. Site-specific features of each plant were characterized by the distance to the nearest flowering conspecific, measured between the edges of the plants, and a quantitative estimate of the forest canopy cover above it. We used compass-referenced hemispherical photographs of the forest canopy taken around the midpoint of the flowering season to estimate canopy cover above individual plants. These estimates were then used to indirectly characterize the site-specific light environment and, more specifically, the mean daily amount of solar radiation received by each plant (Chazdon \& Field, 1987; Becker, Erhart \& Smith, 1989). The cumulative light level reaching a location on the forest floor is a complex function of the size, shape, and orientation of the portion of the sky hemisphere that is visible from it (Canham, 1988; Yoshida, Yanagisawa \& Kamitani, 1998). Although hemispherical photographs may sometimes produce biased estimates of canopy gap fractions (Bellow \& Nair, 2003), they are generally considered a robust indirect method of estimating light transmittance to the forest understory (Lhotka \& Loewenstein, 2006), and we are confident that the accuracy of this method was suitable for the purposes of this study. Photographs were taken vertically from the top of each plant using a $180^{\circ}$ hemispherical (fisheye) lens (Nikon FC-E8) and a digital camera (Nikon Coolpix 995) assembled on a tripod. The circular images depicting the canopy above each plant were analyzed using the program WinPhot 5.0 (Steege, 1996) to obtain the percentage of canopy cover. Two plants with defective hemispherical photographs were excluded from the analyses, which finally comprised data for $n=82$ plants.

\section{POLLINATION SUCCESS}

At the end of the flowering period, 12 flowers were collected from each study plant and preserved in FAA solution (2.5\% formaldehyde, $2.5 \%$ acetic acid, 95\% ethanol) until dissection and measurement. Pistils were softened in $1 \mathrm{~N}$ $\mathrm{KOH}$ at $65^{\circ} \mathrm{C}$ for $20 \mathrm{~min}$, rinsed with distilled water, and stained for $20 \mathrm{~min}$ at $65^{\circ} \mathrm{C}$ in decolourized aniline blue. The number of pollen tubes in each pistil were counted under an epifluorescence microscope for a total of $n=984$ flowers. The maternal pollination success of individual plants was then estimated using 2 different but complementary variables: the mean number of pollen tubes per pistil, which provided an estimate of successful visits, and the proportion of flowers within a plant without pollen tubes (unfertilized flowers hereafter), which provided an index of the frequency of pollination failure.

\section{DATA ANALYSES}

All statistical analyses were performed using the SAS statistical package (SAS Institute, 2002). The effects of sex, distance to nearest neighbour, percent canopy cover, and the pairwise interactions sex $\times$ distance and sex $\times$ cover on the mean number of pollen tubes per pistil and the proportion of unfertilized flowers per plant were analyzed by fitting generalized linear mixed models to the data using the GLIMMIX procedure (as implemented in SAS version 9.1.3; Littell et al., 1996), with Poisson and binomial error distributions, respectively. The 2 models fitted the data closely, as shown by normal distribution of residuals and generalized $\chi^{2} /$ degrees of freedom ratios close to unity (1.03 and 1.42 , respectively). The three-way interac-

TABLE I. Site elevation and descriptive statistics for the distance to the nearest flowering conspecific and canopy cover of Daphne laureola study plants $(n=12$ per site). Shown are the average values (SD in parentheses) and the $25 \%$ and $75 \%$ percentiles (P25 and P75, respectively).

\begin{tabular}{|c|c|c|c|c|c|c|c|}
\hline \multirow[t]{2}{*}{ Site } & \multirow[t]{2}{*}{ Elevation (m asl) } & \multicolumn{3}{|c|}{ Distance (m) } & \multicolumn{3}{|c|}{ Canopy cover $(\%)$} \\
\hline & & Mean (SD) & $\mathrm{P} 25$ & P75 & Mean (SD) & P25 & P75 \\
\hline Coto del Valle & 950 & $1.3(1.3)$ & 0.7 & 1.4 & $72.0(4.6)$ & 67.2 & 76.3 \\
\hline Cuevas Bermejas & 1210 & $1.7(1.1)$ & 1.1 & 2.9 & $82.0(1.8)$ & 81.6 & 83.0 \\
\hline Roblehondo & 1235 & $2.9(2.7)$ & 1.1 & 4.0 & $79.5(4.0)$ & 77.1 & 82.3 \\
\hline Prados de Navahondona & 1490 & $0.6(0.5)$ & 0.1 & 1.0 & $76.2(2.1)$ & 75.3 & 77.5 \\
\hline Cañada de la Medianega & 1560 & $1.0(1.7)$ & 0.0 & 5.5 & $71.7(4.7)$ & 69.9 & 75.3 \\
\hline Cañada del Espino & 1575 & $0.3(0.4)$ & 0.0 & 0.8 & $78.0(1.3)$ & 77.1 & 78.6 \\
\hline Puerto Llano & 1800 & $1.2(2.2)$ & 0.0 & 0.5 & $68.3(6.3)$ & 62.4 & 74.5 \\
\hline All combined & & $2.0(5.2)$ & 0.0 & 1.6 & $75.7(5.8)$ & 71.9 & 79.5 \\
\hline
\end{tabular}


tion sex $\times$ distance $\times$ cover was not statistically significant $(P>0.30)$ and was excluded from the final models. Since our focus here was on individual variation within populations rather than on possible differences among populations, the effect of populations was considered as random. Unless otherwise stated, least-squares means $( \pm \mathrm{SE})$ estimating the marginal means corresponding to the fixed effects over a balanced population are shown.

\section{Results}

The distance from focal plants to the nearest conspecific ranged between 0 and $42.4 \mathrm{~m}$ (all populations combined). Although this broad range was heavily influenced by a few extreme data, among-plant variation in distance to the nearest conspecific was still apparent when the interquartile range, a more robust variation statistic defined by the 25 and $75 \%$ percentiles, was considered (Table I). As expected for an understory species, percent canopy cover was relatively high at all sites (Table I), but it was also variable between individuals, ranging between 61 and $86 \%$ (all populations combined). Distance to the nearest neighbour and canopy cover were not significantly correlated across plants in our sample $\left(r_{s}=0.17, n=82, P=0.13\right)$.

Female and hermaphrodite plants did not differ significantly in either distance to the nearest conspecific $\left(\chi^{2}{ }_{1}=0.92, P=0.59\right.$; Kruskal-Wallis test) or percent canopy cover $\left(\chi^{2}{ }_{1}=0.02, P=0.89\right)$. On average, and for all populations combined, flowers of female plants were pollinated significantly less often than flowers of hermaphrodites (proportion of unfertilized flowers/plant $=0.64 \pm 0.04$ and $0.14 \pm 0.02$ for females and hermaphrodites, respectively; $\left.\chi^{2}{ }_{1}=51.4, P<0.0001\right)$. Flowers of female plants also had significantly fewer pollen tubes/pistil on average than flowers of hermaphrodites $(1.43 \pm 0.26$ and $14.16 \pm 1.01$ pollen tubes for females and hermaphrodites, respectively; $\left.\chi_{1}^{2}=60.8, P<0.0001\right)$.

The absence of differences between sexes in both sitespecific variables in our sample facilitated unbiased tests of sex-dependent effects on pollination success. Results of the generalized linear mixed models testing for the effects of sex, canopy cover, distance to nearest conspecific, and their interactions on the measurements of pollination success are summarized in Table II. Of the 3 main effects tested, plant sex was the only non-significant one, which contrasts with the significant differences between sexes noted earlier, obtained when the data are analyzed without simultaneously considering individual differences in canopy cover and distance to nearest neighbour. Percent canopy cover had a barely significant effect on pollen tubes per flower but not on the proportion of unfertilized flowers. Distance to the nearest conspecific had highly significant effects on both the number of pollen tubes and the proportion of unfertilized flowers. These results clearly demonstrate that the 2 site-specific plant features considered in this study are important determinants of the pollination success of individual $D$. laureola plants. The sign and magnitude of the effects of site-specific features on pollination success, however, are contingent on plant sex, as shown by the statistical significance of the 2 interactions included in the model
TABLE II. Results of the generalized linear mixed models testing for the effect of sex, canopy cover, and distance to the nearest conspecific on 2 complementary measurements of pollination success of Daphne laureola individuals. Statistically significant effects are shown in bold type. The interaction $\mathrm{S} \times \mathrm{C} \times \mathrm{D}$ was far from significant and consequently excluded from the final models. Population was included as a random effect in models.

\begin{tabular}{lcccc}
\hline \hline Effect & \multicolumn{2}{c}{$\begin{array}{c}\text { Number of pollen } \\
\text { tubes per flower }\end{array}$} & \multicolumn{2}{c}{$\begin{array}{c}\text { Proportion of } \\
\text { unfertilized flowers }\end{array}$} \\
& $F_{1,70}$ & $P$ & $F_{1,70}$ & $P$ \\
\hline Sex (S) & 0.03 & 0.863 & 0.21 & 0.647 \\
Cover (C) & 4.68 & $\mathbf{0 . 0 3 4}$ & 0.75 & 0.391 \\
Distance (D) & 7.33 & $\mathbf{0 . 0 0 9}$ & 10.52 & $\mathbf{0 . 0 0 2}$ \\
S $\times$ C & 9.16 & $\mathbf{0 . 0 0 4}$ & 5.20 & $\mathbf{0 . 0 2 6}$ \\
S $\times$ D & 6.12 & $\mathbf{0 . 0 1 6}$ & 6.21 & $\mathbf{0 . 0 1 5}$ \\
\hline \hline
\end{tabular}

(Table II). Similar results were obtained when the analyses were conducted on the $n=54$ plants for which the closest neighbour was a potential pollen donor, i.e., a hermaphrodite plant (not shown).

The effects of plant canopy cover and distance to nearest neighbour on individual pollination success were different for female and hermaphrodite plants, as revealed by statistically significant sex $\times$ cover and sex $\times$ distance interactions in Table II. The nature of these interactions is revealed by plotting the original data separately for the 2 sexes (Figure 1). Females and hermaphrodites differed in the slope of the relationship linking pollination success and percent canopy cover (Figure 1a,c). The pollination success - canopy cover relationships were not significant for hermaphrodites ( $P \geq 0.22$; Figure 1a,c, open dots). In contrast, in the case of female plants there was a significant direct relationship between pollen tubes per flower and canopy cover $\left(F_{1,32}=11.61, P=0.002\right)$ and an inverse relationship between the proportion of unfertilized flowers and canopy cover $\left(F_{1,32}=6.35, P=0.017\right)$. Plants of both sexes experienced significant declines in pollination success with increasing distance to the nearest conspecific, but the effect was most marked for females (Figure 1d). The general picture emerging from examination of the sex $\times$ cover and sex $\times$ distance interactions, therefore, is that the pollination success of female plants was much more sensitive to small-scale variations in site-specific features than that of hermaphrodites.

\section{Discussion}

The separation of sexual functions in plants may be associated with physiological and ecological differences between individuals of different sexes that could eventually contribute to the evolution and maintenance of polymorphic breeding systems (Bierzychudek \& Eckhart, 1988; Freeman et al., 1997; Dawson \& Geber, 1999). Indeed, spatial segregation of sexes along environmental gradients has been repeatedly reported for dioecious (Bierzychudek \& Eckhart, 1988; Freeman et al., 1997) and, less frequently, subdioecious species (El-Keblawy \& Freeman, 1999; Schultz, 2003). Although empirical evidence of the proximate mechanisms is scarce, spatial segregation of sexes would be favoured, in theory, in populations with heterogeneous environments whenever sex-differential reproductive success 

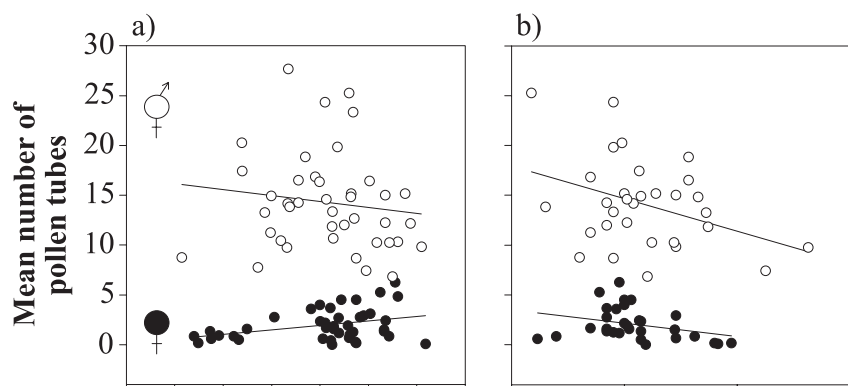

c)

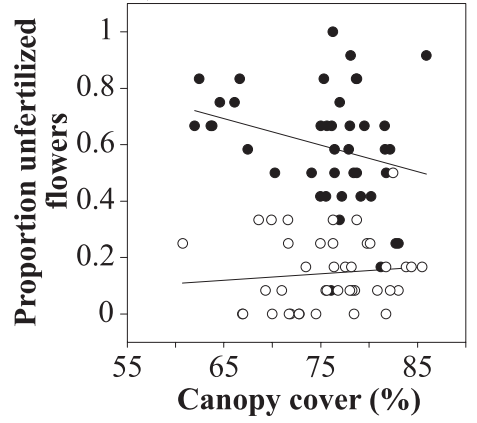

d)

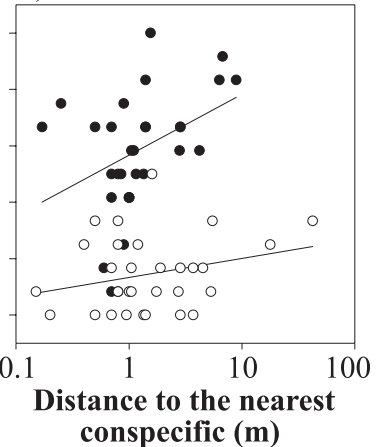

FIGURE 1. Relationships between estimates of the maternal pollination success and site-specific features of female (filled dots) and hermaphrodite (open dots) individuals of Daphne laureola. Upper row: variation of the mean number of pollen tubes per pistil with (a) the plant's canopy cover and (b) distance to the nearest conspecific. Lower row: relationship between the proportion of unfertilized flowers and the plant's (c) canopy cover and (d) distance to the nearest conspecific. Note that the regression lines in panels $\mathrm{b}$ and $\mathrm{d}$ are plotted only for illustrative purposes because zeroes in horizontal axis were not represented due to the logarithmic scale.

or sex-differential mortality occurs across environments (Bierzychudek \& Eckhart, 1988). This study has shown that individual pollination success of females and hermaphrodites in the gynodioecious $D$. laureola was affected differentially by the 2 site-specific features considered, a finding suggesting that spatial segregation of sexes may potentially occur in this species. In seeming contradiction with this hypothesis, we found that differences between sexes for both distance to the nearest conspecific and canopy cover were not statistically significant in our study sample. This result, however, does not necessarily rule out the possibility of spatial segregation of sexes or sexual selection of microhabitat occurring in D. laureola, because our sampling design involved rather few randomly sampled individuals in each of several populations instead of analyzing comparatively the site-specific characteristics of random samples of plants of the 2 sexes within populations, which would have required much larger samples per site. Elucidation of the potential consequences of observed patterns in terms of spatial segregation of sexes, and their possible correlates with local sex ratios (Graff, 1999), must thus await future studies.

Distance-dependent fecundity of female plants related to variation in pollination success has been previously reported for both dioecious (de Jong, Batenburg \& Klinkhamer, 2005) and gynodioecious insect-pollinated species (Widén \& Widén, 1990). In this study, individual pollination success of $D$. laureola was negatively affected by distance to the nearest conspecific, and as expected, the effect was stronger for females than for the self-compatible hermaphrodites of this winter-flowering gynodioecious plant. The quantitative differences in pollination success reported here are expected to be particularly significant for female individuals. Daphne laureola flowers have a single ovule, and the mean number of pollen tubes per flower of female plants (1.4) was only slightly above the minimum indispensable for setting a fruit. Furthermore, the proportion of unfertilized flowers in females (which is negatively correlated with fruit set; Alonso, 2005) ranged between 100 and 8\%, which likewise indicates a higher frequency of insufficient pollinations among females when compared to hermaphrodites, for which the proportion of unfertilized flowers per plant was always below 50\% (Figure 1d). While variations in the distance to the nearest conspecific at the relatively small scale of $0-10 \mathrm{~m}$ are consequential in terms of fitness for female plants, the female function of hermaphrodite individuals was independent of distance to the nearest conspecific (Figure $1 b, d$ ). This finding is congruent with the extremely high selfing rates obtained in a subset of the populations studied here (Medrano, Alonso \& Herrera, 2005), which would suggest a high frequency of pollinator-induced selfing and/or geitonogamous pollinations, and hence a relative independence of pollinator movements, among hermaphrodite plants. However, the possibility that among-plant differences in spatial isolation may affect pollination quality (e.g., proportions of self and cross pollen received) and the outcrossing rates of hermaphrodites' progenies cannot be discarded (see, e.g., van Treuren et al., 1993; García et al., 2005).

Solar irradiance and ambient temperature may influence the frequency and identity of floral visitors to individual plants through differences in pollinator thermal biology and microhabitat selection (Herrera, 1995; 1997) and in the pollinating efficiency of floral visits due to changes in stigma receptivity and pollen germination rates (Murcia, 1990; Orueta, 2002; Galen \& Stanton, 2003; Hedhly, Hormaza $\&$ Herrero, 2005). Scarcity of information on the effect of the solar irradiance environment on the pollination success of individual understory plants (Herrera, 1995; SánchezLafuente et al., 2005), and the absence of such information for gynodioecious species, prevented formulating any plausible a priori hypothesis on the possible differential effects of canopy cover on the pollination success of plants of the 2 sexes. In principle, pollination success of understory hermaphroditic species flowering under adverse environmental conditions for pollinator activity is expected to be affected by variations in microclimate (Herrera, 1995), and thus both female and hermaphrodite plants were expected to be affected. We found, however, a highly significant sex $x$ cover interaction effect on measurements of individual pollination success, and this effect cannot be attributed to potential artifacts due to covariation of cover with plant distance since these 2 variables were uncorrelated in our sample. Among female individuals, the number of pollen tubes/pistil decreased and the proportion of unfertilized flowers increased from closed to more open sites, while hermaphrodites showed non-significant trends. The contrasting sign of the relationship between cover and pollination suc- 
cess for the 2 genders is expected to generate a fine-scale, within-habitat mosaic in the magnitude of the pollination advantage of hermaphrodite individuals, which should be greater in more open, sunny locations where ectothermic pollinators should be more active. Indeed, the most frequent pollinator observed in our study region, the ectothermic pollen-feeding beetle Meligethes elongatus, shows definite preference for sunny locations (providing a favourable thermal environment) and hermaphrodite flowers (providing pollen as food) (Alonso, 2004). Beetle ability to discriminate by visual and olfactory cues against the pollenless individual females, and/or the residence time spent crawling among their flowers (see Cook et al., 2002; Cook, Murray \& Williams, 2004 for M. aeneus), would decline in the more closed locations. In relation to this interpretation, it is interesting to note that Sánchez-Lafuente et al. (2005) found no effects of the irradiance environment on the pollination success of Helleborus foetidus, another understory winter-flowering species that coexists locally with D. laureola in our study region. In contrast to beetle-pollinated $D$. laureola, $H$. foetidus is pollinated by bumblebees, whose endothermic capacity would make them independent of sunny patches in the forest. Certainly, the influence of canopy cover on D. laureola pollination success could vary geographically if the main pollinator varies regionally, since different insect species might be differentially affected by the solar irradiance environment (Herrera, 1997).

Although we did not measure it, the male component of pollination success in hermaphrodite plants could be also affected by site-specific effects dependent on the irradiance environment. Given the very high levels of inbreeding depression exhibited by selfed progenies in some of our study populations (Medrano, Alonso \& Herrera, 2005), it may be predicted that siring success of hermaphrodites would be improved with increasing canopy cover because of the increased likelihood of pollen transfer to nearby female plants under shadier locations. Both the site-specific differences in gender relative maternal pollination success and the contrasting consequences for male and female functions of hermaphrodites might contribute to the persistence of gynodioecy of $D$. laureola in our study region.

It is well known that successional stage, treefalls, and other microscale disturbances determine a gap-dynamics in forests that can strongly influence the composition and population dynamics of plant communities (Laska, 2001). Although it has been less frequently studied from an individual-centred perspective, gap dynamics may also be consequential for the fitness of individual plants (Laska, 2001). The results reported here highlight that the pollination success of an understory species may be highly dependent on site-specific effects such as canopy cover and distance to conspecifics, and consequently on any natural or anthropogenic disturbance. They also underline that such effects could vary between male and female reproductive functions, suggesting that more studies on within-population, site-specific effects on female and male functions and in species with polymorphic breeding systems are required to better understand the possible significance of the small-scale ecological context in breeding system evolution.

\section{Acknowledgements}

We thank M. García, A. Manzaneda, and N. Varo for lab and field assistance, two anonymous referees for their comments on the manuscript, and the Consejería de Medio Ambiente, Junta de Andalucía for authorizing this work in Cazorla. C. Alonso also acknowledges a Ramón y Cajal grant provided by the Spanish Ministerio de Educación y Ciencia. The study was funded by the Spanish Ministerio de Educación y Ciencia through research projects BOS2003-02235 and CGL2006-01355/BOS and the Consejería de Innovación, Ciencia y Empresa, Junta de Andalucía, through Excellence Research Project RNM156-2005.

\section{Literature cited}

Alonso, C., 2004. Early blooming challenges: Extended flowering season, diverse pollinator assemblage, and the reproductive success of gynodioecious Daphne laureola. Annals of Botany, 93: 61-66.

Alonso, C., 2005. Pollination success across an elevation and sex ratio gradient in gynodioecious Daphne laureola. American Journal of Botany, 92: 1264-1269.

Alonso, C. \& C. M. Herrera, 2001. Neither vegetative nor reproductive advantages account for high frequency of male-steriles in southern Spanish gynodioecious Daphne laureola. American Journal of Botany, 88: 1016-1024.

Alonso, C., P. Mutikainen \& C. M. Herrera, 2007. Ecological context of breeding system variation: Sex, size and pollination in a (predominantly) gynodioecious shrub. Annals of Botany, 100: $1547-1556$.

Ashman, T. L., 2006. The evolution of separate sexes: A focus on the ecological context. Pages 204-222 in L. D. Harder \& S. C. H. Barrett (eds.). Ecology and Evolution of Flowers. Oxford University Press, Oxford.

Barr, C. M., 2004. Soil moisture and sex ratio in a plant with nuclear-cytoplasmic sex inheritance. Proceedings of the Royal Society of London, B, 271: 1935-1939.

Beattie, A. J., 1971. Itinerant pollinators in a forest. Madroño, 21: 120-124.

Becker, P., D. W. Erhart \& A. P. Smith, 1989. Analysis of forest light environments. Part I. Computerized estimation of solar radiation from hemispherical canopy photographs. Agricultural and Forest Meteorology, 44: 217-232.

Bellow, J. G. \& P. K. R. Nair, 2003. Comparing common methods for assessing understory light availability in shaded-perennial agroforestry systems. Agricultural and Forest Meteorology, 114: 197-211.

Bierzychudek, P. \& V. Eckhart, 1988. Spatial segregation of the sexes of dioecious plants. American Naturalist, 132: 34-43.

Canham, C. D., 1988. An index for understory light levels in and around canopy gaps. Ecology, 69: 1634-1638.

Castroviejo, S., C. Aedo, M. Laínz, P. Montserrat, R. Morales, F. Muñoz Garmendia, G. Nieto Felinier, J. Paiva (eds.), 1997. Flora Iberica. Real Jardin Botánica, CSIC, Madrid, Spain.

Caruso, C. M., S. B. Peterson \& C. E. Ridley, 2003. Natural selection of floral traits of Lobelia (Lobeliaceae): Spatial and temporal variation. American Journal of Botany, 90: 1333-1340.

Chazdon, R. L. \& C. B. Field, 1987. Photographic estimation of photosynthetically active radiation: Evaluation of a computerized technique. Oecologia, 73: 525-532.

Cook, S. M., D. A. Murray \& I. H. Williams, 2004. Do pollen beetles need pollen? The effect of pollen on oviposition, survival, and development of a flower-feeding herbivore. Ecological Entomology, 29: 164-173. 
Cook, S. M., E. Bartlet, D. A. Murray \& I. H. Williams, 2002. The role of pollen odour in the attraction of pollen beetles to oilseed rape flowers. Entomologia Experimentalis et Applicata, 104: 43-50.

Dawson, T. E. \& M. A. Geber, 1999. Sexual dimorphism in physiology and morphology. Pages 175-215 in M. A. Geber, T. E. Dawson \& L. F. Delph (eds.). Gender and Sexual Dimorphism in Flowering Plants. Springer-Verlag, Berlin.

De Jong, T. J., J. C. Batenburg \& P. G. L. Klinkhamer, 2005. Distance-dependent pollen limitation of seed set in some insectpollinated dioecious plants. Acta Oecologica, 28: 331-335.

Eckert, C. G., 2002. Effect of geographical variation in pollinator fauna on the mating system of Decodon verticillatus (Lythraceae). International Journal of Plant Sciences, 163: 123-132.

Eckhart, V. M., 1992. Spatio-temporal variation in abundance and variation in foraging behavior of the pollinators of gynodioecious Phacelia linearis (Hydrophyllaceae). Oikos, 64: 573-586.

El-Keblawy, A. \& D. C. Freeman, 1999. Spatial segregation by gender of the subdioecious shrub Thymelaea hirsuta in the Egyptian desert. International Journal of Plant Sciences, 160: 341-350.

Feldman, T. S., 2006. Pollinator aggregative and functional responses to flower density: Does pollinator response to patches of plants accelerate at low densities? Oikos, 115: 128-140.

Freeman, D. C., J. Lovett Doust, A. El-Keblawy, K. J. Miglia \& E. D. McArthur, 1997. Sexual specialization and inbreeding avoidance in the evolution of dioecy. Botanical Review, 63: 65-92.

Galen, C., 1999. Why do flowers vary? The functional ecology of variation in flower size and form within natural plant populations. BioScience, 49: 631-640.

Galen, C. \& M. L. Stanton, 2003. Sunny-side up: Flower heliotropism as a source of parental environmental effects on pollen quality and performance in the snow buttercup, Ranunculus adoneus (Ranunculaceae). American Journal of Botany, 90: 724-729.

García, C., J. M. Arroyo, J. A. Godoy \& P. Jordano, 2005. Mating patterns, pollen dispersal, and the ecological maternal neighbourhood in a Prunus mahaleb L. population. Molecular Ecology, 14: 1821-1830.

Graff, A., 1999. Population sex structure and reproductive fitness in gynodioecious Sidalcea malviflora malviflora (Malvaceae). Evolution, 53: 1714-1722.

Hedhly, A., J. I. Hormaza \& M. Herrero, 2005. The effect of temperature on pollen germination, pollen tube growth, and stigmatic receptivity in peach. Plant Biology, 7: 476-483.

Herrera, C. M., 1995. Microclimate and individual variation in pollinators: Flowering plants are more than their flowers. Ecology, 76: $1516-1524$

Herrera, C. M., 1996. Floral traits and plant adaptation to insect pollinators: A devil's advocate approach. Pages 65-87 in D. G. Lloyd \& S. C. H. Barrett (eds.). Floral Biology: Studies on Floral Evolution in Animal-Pollinated Plants. Chapman \& Hall, New York, New York.

Herrera, C. M., 1997. Thermal biology and foraging responses of insect pollinators to the forest floor irradiance mosaic. Oikos, 78: 601-611.

Herrera, C. M., M. C. Castellanos \& M. Medrano, 2006. Geographical context of floral evolution: Towards an improved research programme in floral diversification. Pages 278-294 in L. D. Harder \& S. C. H. Barrett (eds.). Ecology and Evolution of Flowers. Oxford University Press, Oxford.
Herrera, J., 2005. Flower size variation in Rosmarinus officinalis: Individuals, populations and habitats. Annals of Botany, 95: 431-437.

Karban, R., 1997. Neighbourhood affects a plant's risk of herbivory and subsequent success. Ecological Entomology, 22: 433-439.

Kunin, W. E., 1992. Density and reproductive success in wild populations of Diplotaxis erucoides (Brassicaceae). Oecologia, 91: 129-133.

Laska, G., 2001. The disturbance and vegetation dynamics: A review and an alternative framework. Plant Ecology, 157: 77-99.

Laverty, T. M., 1992. Plant interactions for pollinator visits: A test of the magnet species effect. Oecologia, 89: 502-508.

Lhotka, J. M. \& E. F. Loewenstein, 2006. Indirect measures for characterizing light along a gradient of mixed-hardwood riparian forest canopy structures. Forest Ecology and Management, 226: $310-318$.

Littell, R. C., G. A. Milliken, W. W. Stroup \& R. D. Wolfinger, 1996. SAS System for Mixed Models. SAS Institute, Cary, North Carolina.

Medrano, M., C. Alonso \& C. M. Herrera, 2005. Mating system, sex ratio, and persistence of females in the gynodioecious shrub Daphne laureola L. (Thymelaeaceae). Heredity, 94: 37-43.

Metcalfe, D. B. \& W. E. Kunin, 2006. The effects of plant density upon pollination success, reproductive effort and fruit parasitism in Cistus ladanifer L. (Cistaceae). Plant Ecology, 185: 41-47.

Murcia, C., 1990. Effect of floral morphology and temperature on pollen receipt and removal in Ipomoea trichocarpa. Ecology, 71: 1098-1109.

Orueta, D., 2002. Thermal relationships between Calendula arvensis inflorescences and Usia aurata bombyliid flies. Ecology, 83: $3073-3085$

Pellmyr, O., 2002. Pollination by animals. Pages 157-184 in C. M. Herrera \& O. Pellmyr (eds.). Plant-Animal Interactions. An Evolutionary Approach. Blackwell, Oxford.

Petanidou, T. \& E. Smets, 1996. Does temperature stress induce nectar secretion in Mediterranean plants? New Phytologist, 133: 513-518.

Peterson, M. A., 1997. Host plant phenology and butterfly dispersal: Causes and consequences of uphill movement. Ecology, 78: $167-180$

Pettersson, M. W., 1997. Solitary plants do as well as clumped ones in Silene uniflora (Caryophyllaceae). Ecography, 20: 375-382.

Price, M. V., N. M. Waser, R. E. Irwin, D. R. Campbell \& A. K. Brody, 2005. Temporal and spatial variation in pollination of a montane herb: A seven-year study. Ecology, 86: 2106-2116.

Salonen, V., 1994. Growth and reproduction of Rubus saxatilis in relation to light availability. Acta Oecologica, 15: 485-493.

Sánchez-Lafuente, A. M., J. Guitián, M. Medrano, C. M. Herrera, P. J. Rey \& X. Cerdá, 2005. Plant traits, environmental factors, and pollinator visitation in winter-flowering Helleborus foetidus (Ranunculaceae). Annals of Botany, 96: 845-852.

Sapir, Y., A. Shmida \& G. Neeman, 2006. Morning floral heat as a reward to the pollinators of the Oncocyclus irises. Oecologia, 147: 53-59.

SAS Institute, 2002. SAS for Windows (version 9.1.3). SAS Institute, Cary, North Carolina.

Schemske, D. W. \& P. Bierzychudek, 2001. Evolution of flower color in desert annual Linanthus parryae: Wright revisited. Evolution, 55: 1269-1282.

Schultz, S. T., 2003. Sexual dimorphism in gynodioecious Sidalcea hirtipes (Malvaceae). I. Seed, fruit and ecophysiology. International Journal of Plant Sciences, 164: 165-173. 
Seymour, R. S., C. R. White \& M. Gibernau, 2003. Heat reward for insect pollinators. Nature, 426: 243-244.

Steege, H. T., 1996. WinPhot 5: A Programme to Analyze Vegetation Indices, Light and Light Quality from Hemispherical Photographs. Tropenbos Guyana Reports 95-2, Tropenbos Guyana Programme, Georgetown, Guyana [Online] URL: http://www.bio.uu.nl/ herba/Guyana/winphot/wp_index.htm

Totland, O., 2001. Environment-dependent pollen limitation and selection on floral traits in an alpine species. Ecology, 82: 2233-2244.

Utelli, A.-B. \& B. A. Roy, 2001. Causes and consequences of floral damage in Aconitum lycoctonum at high and low elevations in Switzerland. Oecologia, 127: 266-273.
Van Treuren, R., R. Bijlsma, N. J. Ouborg \& W. Van Delden, 1993. The effects of population size and plant density on outcrossing rates in locally endangered Salvia pratensis. Evolution, 47: 1094-1104.

Warren, S. D., K. T. Harper \& G. M. Booth, 1988. Elevational distribution of insect pollinators. American Midland Naturalist, 120: 325-330.

Widén, B. \& M. Widén, 1990. Pollen limitation and distance-dependent fecundity in females of the clonal gynodioecious herb Glechoma hederacea (Lamiaceae). Oecologia, 83: 191-196.

Yoshida, T., Y. Yanagisawa \& T. Kamitani, 1998. An empirical model for predicting the gap light index in an even-aged oak stand. Forest Ecology and Management, 109: 85-89. 